\title{
Dump Truck Driver Dies After Being Entangled In Power-Take-Off Drive Shaft
}

\section{Incident Number: 06KY079}

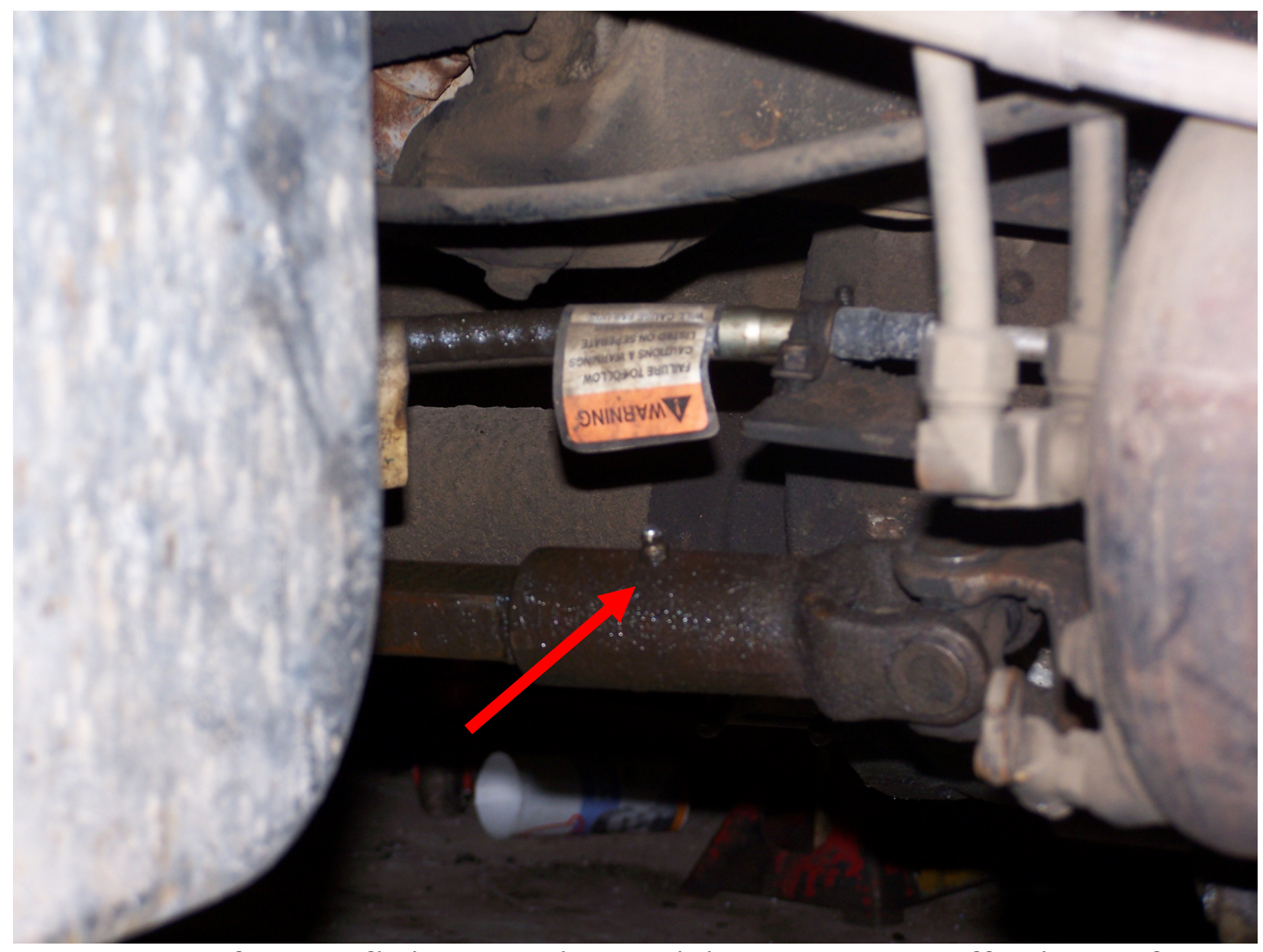

Photograph of grease fitting on universal joint power-take-off drive shaft that caught worker's coat

Kentucky Fatality Assessment and Control Evaluation Program Kentucky Injury Prevention and Research Center 333 Waller Avenue

Suite 206

Lexington, Kentucky 40504

Phone: 859-323-2981

Fax: 859-257-3909

www.kiprc.uky.edu

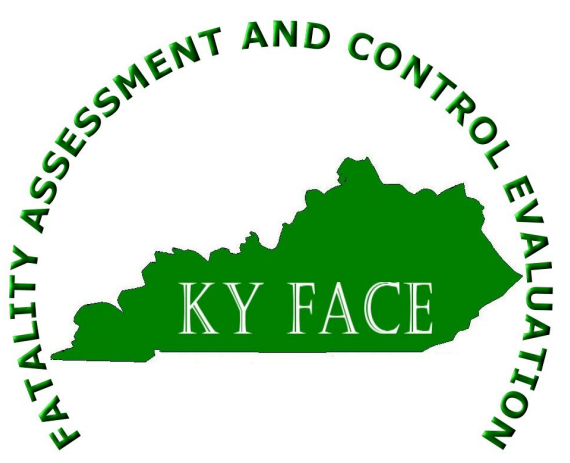




\title{
Kentucky Fatality Assessment and Control Evaluation Program Incident Number: $\quad 06 \mathrm{KY} 079$ \\ Release Date: \\ Subject: \\ January 22, 2008 \\ Dump Truck Driver Dies After Being Entangled \\ In Power-Take-Off Drive Shaft
}

\begin{abstract}
Summary
During the fall of 2006, a 25-year-old male company dump truck driver (decedent) died when he became entangled in the drive shaft of the power-take-off pump (PTO) underneath a dump truck. $\mathrm{He}$ and four other dump truck drivers were waiting to have their trucks filled with asphalt when one of the other drivers (Driver 1) began having difficulty with the bed of his truck raising and lowering properly. Another driver (Driver 2) attempted to assist Driver 1 with the problem, but was unsuccessful. Driver 1 decided to inform the plant manager (Owner 1) of the situation and request assistance from the company's mechanics to fix the problem. While Driver 1 was speaking with Owner 1, the decedent (Driver 3), unbeknownst to anyone else, crawled under the dump truck of Driver 1 to see if he could fix the problem.
\end{abstract}

As Driver 3 lay under the idling truck's spinning PTO shaft, his coat sleeve became entangled in the grease fitting on the front universal joint. He was twisted onto the shaft and under the bed of the dump truck. When Driver 1 returned to his truck to wait for assistance from the company mechanic, he found the decedent caught in the PTO drive shaft underneath the truck. Driver 1 yelled to Owner 1 in the tower to call emergency medical services to the scene. While Owner 1 called 911, he called Owner 2 to the scene. Owner 2 found the decedent entangled in the PTO shaft and with the assistance from Driver 4, they proceeded to cut his clothing to free him from the shaft. Owner 2 tried to resuscitate Driver 3 (decedent) while EMS was enroute. Emergency medical services arrived six minutes later, determined the driver was in critical condition, and notified emergency air care. As emergency medical personnel placed Driver 3 in an ambulance and transported him to a nearby field where the air ambulance waited, he died. Air transport was cancelled and the local coroner was contacted who arrived and declared Driver 3 dead at the scene.

To prevent future occurrences of similar incidents, the following recommendations have been made:

Recommendation No. 1: Ensure that trucks are turned in the "off" position and keys removed, prior to driver exiting and leaving the motor vehicle unattended.

Recommendation No. 2: Employers should provide comprehensive safety training for all newly hired personnel including temporary and substitute drivers before they are allowed to work in the field.

Recommendation No. 3: Loose clothing should not be worn while repairing machinery. 
Recommendation No. 4: Employers should require that operators or other competent persons perform daily safety checks on the mobile equipment prior to operating them using an expanded Department of Transportation Inspection form.

Recommendation No. 5: Educate employees about the hazards of PTO's and ensure they do not crawl under, on, or over unguarded power take-off (PTO) drivelines while the PTO is operating.

Recommendation No. 6: Consideration should be given to engineering machine guards for truck power take-off;, equipment should be designed or retrofitted to shield any open, unguarded power take-off drivelines.

\section{Background}

The asphalt paving company the decedent worked for began in 1954. At the time of the incident, approximately 33 people were employed; five office staff, and approximately 27 other workers. There were eight paving crews, and the company garage had two certified mechanics. To be hired, dump truck drivers were required to have a valid commercial driver's license, pass a drug test, successfully pass two test drives with a certified mechanic employed by the company, and undergo company policy training. Safety meetings were held every Monday. Company safety policies were addressed at the company's annual meeting.

Each driver performed the mandatory inspection of their dump trucks as required by the Department of Transportation (Attachment 1), then drove approximately two miles to the company asphalt plant to be loaded. In the spring of 2006, the paving company purchased its own asphalt plant and relocated it approximately 2 miles from the company garage. The plant was producing its own asphalt in the Fall of 2006. The 25-year-old male decedent driver was employed by the company in May 2006. Drivers drove the same dump truck every day. Maintenance on the dump trucks was performed on-site by certified mechanics employed by the company. The drivers worked fifty hours per week. Some drivers worked full-time, other drivers worked as part-time substitute drivers.

The daily routine for the drivers was to report to the garage, pick up their dump truck, and perform the mandatory Department of Transportation truck inspection. After the inspections were completed, the dump truck drivers drove approximately two miles to the asphalt plant and were loaded with asphalt. The drivers would then transport the asphalt to the paving location, dump the asphalt, return to the plant and begin the routine all over again.

The temperatures that day ranged from 36 degrees Fahrenheit to 55 degrees Fahrenheit; averaging approximately 46 degrees Fahrenheit.

\section{Investigation}

On this particular morning, at approximately 7:30 AM, the decedent and four other drivers arrived at the garage, inspected their respective dump trucks, and drove to the asphalt plant two miles away. Once at the asphalt plant, the drivers lined up their dump trucks in two lines and waited to be loaded (see Attachments 2 and 3). As they waited for the asphalt to be loaded, the 
drivers, with their trucks idling, exited their cabs and talked amongst themselves. Driver 1, a substitute driver, informed the group that the bed of his truck was not raising and lowering properly when the switch was activated. Another driver (Driver 2) walked around the truck, looked at the mechanism underneath, and got back out from under the truck. Each driver then returned to the cab of their respective dump truck. With his truck idling and the bed in the lowered position, Driver 1 engaged the parking brake, exited the cab again, crawled underneath the dump truck, and checked the cable which raised and lowered the bed. He then crawled out from underneath the truck and walked to the nearby office tower to inform the plant manager (Owner 1) of the problem and to request assistance from the company mechanics. This took approximately 10 minutes. While Driver 1 was discussing the situation with Owner 1 , the decedent (Driver 3), unbeknownst to the other drivers or management, exited his cab and crawled under the idling dump truck to see if he could solve the problem. The PTO shaft spun as the dump truck idled. A grease fitting on the front of the universal joint of the drive shaft off the PTO pump caught the coat sleeve of Driver 3 and he became entangled around the shaft and under the bed of the dump truck. When Driver 1 returned to his truck to wait for the mechanics, he found Driver 3 entangled in the PTO shaft underneath the truck. Driver 1 yelled to Owner 1 in the tower to call emergency medical services to the scene. Another driver (Driver 4) saw Driver 1 waving his arms and yelling for help. Owner 1 noticed Owner 2 pull into the parking lot when he called EMS and asked him to go to the scene. Owner 2 found the decedent entangled in the PTO shaft under the dump truck. He and Driver 4 cut Driver 3 from the PTO shaft. The owner tried to resuscitate Driver 3 until emergency medical services arrived. Emergency medical services arrived in six minutes. They transported Driver 3 via ambulance to a nearby field where an air ambulance was waiting to transport him to a nearby trauma hospital. Driver 3 died while being transported to the field. Air transport was cancelled, and the local coroner was contacted, who arrived and declared Driver 3 dead at the scene.

\section{Cause of Death}

The death certificates states the cause of death was due to "compression injury of neck and chest with asphyxia".

\section{Recommendations and Discussions}

Recommendation No. 1: Ensure that trucks are turned in the "off" position and keys removed, prior to driver exiting and leaving the motor vehicle unattended.

A standard operating procedure that requires drivers to turn off their truck prior to exiting and leaving the truck unattended should be developed and implemented. Workers should receive training and the policy should be enforced to ensure that drivers follow the standard operating procedure.

Recommendation No. 2: Employers should provide comprehensive safety training for all newly hired personnel including temporary and substitute drivers before they are allowed to work in the field. 
New employees were required to attend new hire training which consisted of topics such as safety, job duties, and company policies. The company had a written safety program which stated that if truck drivers had a problem with a truck they were to notify the garage immediately. New hires were required to understand its contents before being placed in the field. This employee had worked for the company less than six months. Employers should ensure that new hires, including temporary and substitute drivers understand their specific job duties and what they entail. New employees, including temporary and substitute drivers, should also be trained to recognize dangerous situations and how to seek assistance in addressing those situations without putting themselves and other workers at risk of injury.

Recommendation No. 3: Loose clothing should not be worn while repairing machinery.

Employers should ensure all dump truck drivers are trained to understand the dangers of the mechanical components of the trucks they drive. It is important for employees to understand the inherent risks of working around an engaged PTO shaft. Loose clothing such as jackets, and shirts are easily caught by spinning PTO shafts and should not be worn while inspections or repairs are being made.

Recommendation No. 4: Employers should require that operators or other competent persons perform daily safety checks on the mobile equipment prior to operating them using an expanded Department of Transportation Inspection form.

Company drivers were required to complete the Department of Transportation Driver's Vehicle Inspection Report, DVIR, (Attachment) and turn them into the office each day. This was routinely accomplished. The report lists important aspects of the vehicle such as air compressor, air lines, battery, body, brakes, clutches, wheels and rims, windshield wipers, etc., which the driver is required to inspect each time the dump truck is operated. There is a space on the form for the driver to make notes for items not listed on the report that may need to be addressed immediately or in the future. After completing the report, the driver either signs that the vehicle is in satisfactory condition or that defects need to be corrected before the truck should be operated. The DVIR does not compel the driver to check operating mechanisms such as raising or lowering the bed before driving the truck. Companies with dump trucks should expand the DVIR to include specific items such as the truck bed raising and lowering properly before operating the truck. Because of this incident, the employer expanded the requirements of the DVIR to include items such as the bed raising and lowering.

Recommendation No. 5: Educate employees about the hazards of PTO's and ensure they do not crawl under, on, or over unguarded power take-off (PTO) drivelines while the PTO is operating.

Power take-off equipment operates at high speeds to transfer power from construction, motorvehicles and agricultural equipment engines to auxiliary implements, such as pumps, plows, augers, winches, and irrigation equipment. PTO-related injuries are generally severe, most often resulting in badly broken bones, amputations, scalping, disfigurement, or death. Stay away from 
the PTO! Keep close control of hair, shoestrings, and all clothing when working near a PTO driveline. Avoid areas near a moving unguarded PTO driveline.

Recommendation No. 6: Consideration should be given to engineering machine guards for truck power take-offs; equipment should be designed or retrofitted to shield any open, unguarded power take-off drivelines.

Currently, the model of truck involved in the incident does not have any guarding for the PTO. Consideration should be given to developing a guard that would prevent inadvertent contact with moving parts of the PTO. Although the primary prevention strategy for this fatality should be separating drivers from the hazard by eliminating unnecessary exposures, guarding would provide an added level of protection for mechanics, who cannot entirely avoid exposure to PTO's. For example, in this instance, the PTO had to be rotating in order to diagnose the problem. A simple metal covering could act as an effective shield for exposed parts of the PTO, thereby reducing the potential for PTO-related injuries. Since the year this truck was manufactured, the PTO shaft design has been changed and is now located where it is shielded and more difficult to be an entanglement hazard.

\section{Keywords}

Dump truck

Power-take-off drive shaft

PTO

Grease fitting

\section{References}

1) National Ag Safety Database, "Power Take-Off (PTO) Safety", website: http://0www.cdc.gov.mill1.sjlibrary.org/NASD/docs/d000701-d000800/d000745/d000745.html

2) 2005 Society of Automotive Engineers Handbook, Vol. 2, Parts \& Components and OnHighway Vehicles, Section 29, Page 92

3) National Safety Council, "Power-Take-Off (PTO)- Safety", website: http://www.nsc.org/library/facts/agripto.htm

4) North Dakota State University, "Straight Facts About PTO Shafts and Shields", website: http://www.ag.ndsu.edu/pubs/ageng/safety/ae1070w.htm

5) Oregon Fatality Assessment \& Control Evaluation report, "Mechanic killed when collar caught on PTO driveline", http://www.ohsu.edu/croet/face/reports/2006-05-1.pdf

6) Alaska Fatality Assessment \& Control Evaluation report, “Truck Driver Dies From Asphyxiation After Entanglement in Dump Truck Power Take-off (PTO)", http://www.cdc.gov/NIOSH/FACE/stateface/ak/92ak061.html 
7) Michigan Fatality Assessment \& Control Evaluation report, "Farm Youth Died When He Became Entangled in an Unguarded PTO Shaft", National Institute Occupational Safety \& Health website: http://www.cdc.gov/niosh/face/stateface/mi/03mi052.html

\section{Acknowledgements}

Company safety representative

Local coroner

Kentucky Occupational Safety and Health Officer

The Kentucky Fatality Assessment \& Control Evaluation Program (FACE) is funded by a grant from the Centers for Disease Control and the National Institute of Safety and Health. The purpose of FACE is to aid in the research and prevention of occupational fatalities by evaluating events leading to, during, and after a work related fatality. Recommendations are made to help employers and employees to have a safer work environment. For more information about FACE and KIPRC, please visit our website at: www.kiprc.uky.edu 


\section{Attachment 1: Copy of Department of Transportations Daily Driver's Vehicle Inspection Report}

\section{DRIVER'S VEHICLE INSPECTION REPORT}

CARRIER:

ADDRESS:

DATE:

TIME:

A.M.

P.M.

TRACTOR/

TRUCK NO. ODOMETER READING

$\square$ Air Compressor
$\square$ Air Lines
$\square$ Battery
$\square$ Body
$\square$ Brake Accessories
$\square$ Brakes, Parking
$\square$ Brakes, Service
$\square$ Clutch
$\square$ Coupling Devices
$\square$ Defroster/Heater
$\square$ Drive Line
$\square$ Engine
$\square$ Exhaust
$\square$ Fifth Wheel
$\square$ Frame and Assembly
$\square$ Front Axle
$\square$ Fuel Tanks
$\square$ Generator

Horn

Lights

Head - Stop

Tail - Dash

Turn Indicators

$\square$ Mirrors

Muffler

$\square$ Oil Pressure

$\square$ Radiator

$\square$ Rear End

Reflectors

$\square$ Safety Equipment

Fire Extinguisher

Reflective Triangles

Flags - Flares - Fusees

Spare Bulbs \& Fuses

Spare Seal Beam

TRAILER(S) NO.(S)

\section{$\square$ Brake Connections \\ $\square$ Brakes \\ $\square$ Coupling Devices \\ Coupling (King) Pin \\ Doors}

Remarks:
Hitch
$\square$ Landing Gear
Lights - All
Roof
Suspension System

Suspension System

Starter

Steering

Tachograph

Tires

Tire Chains

Transmission

Wheels and Rims

Windows

Windshield Wipers

Other

\footnotetext{
L.

\section{$\square$ CONDITION OF THE ABOVE VEHICLE IS SATISFACTORY}

DRIVER'S SIGNATURE:

$\square$ ABOVE DEFECTS CORRECTED

$\square$ ABOVE DEFECTS NEED NOT BE CORRECTED FOR SAFE OPERATION OF VEHICLE

MECHANIC'S SIGNATURE: DATE

Tarpaulin

Tires

Wheels and Rims

Other 
Attachment 2: Photo of asphalt plant. Diagram of how trucks were lined up on next page.

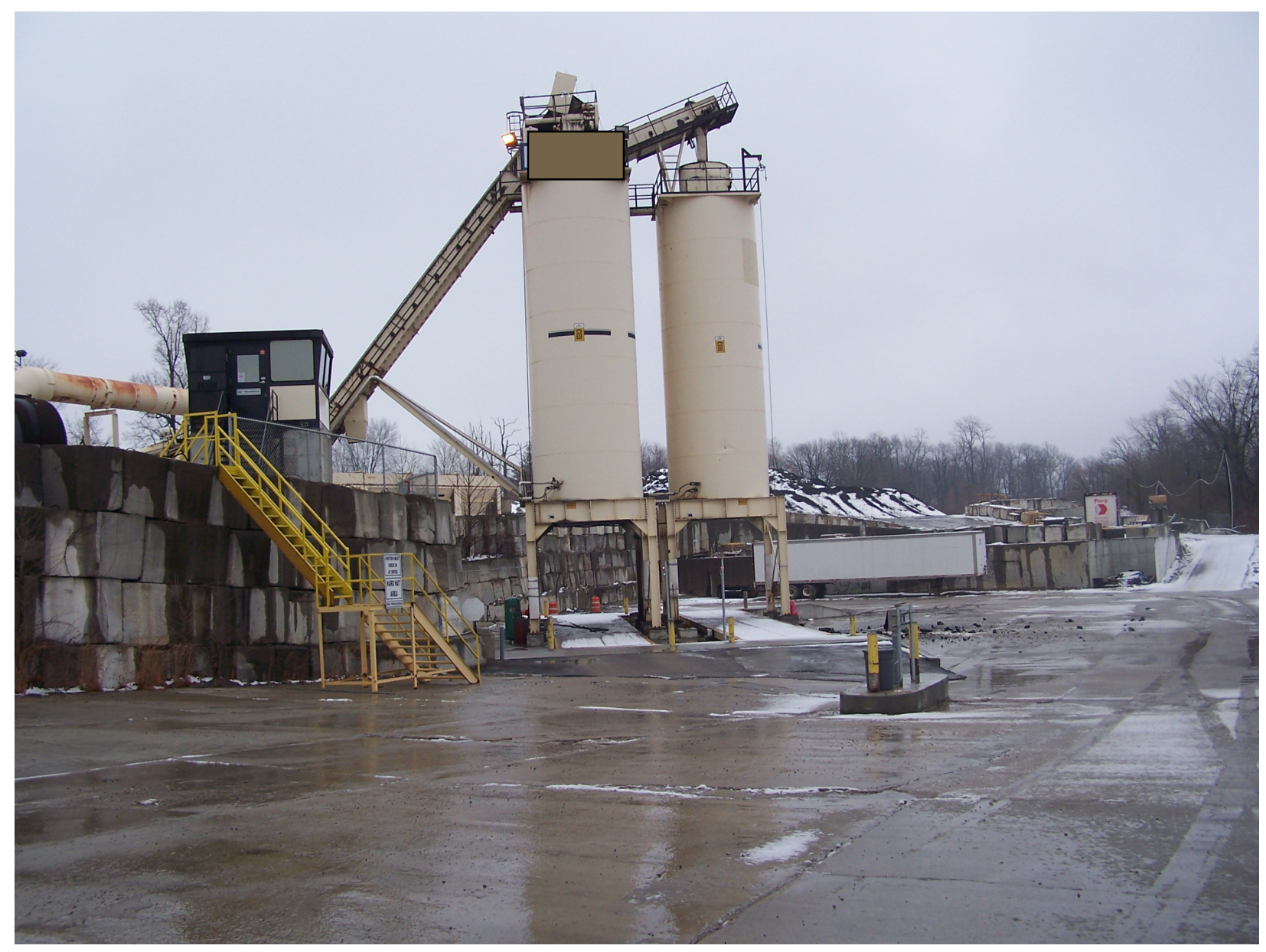




\section{Attachment 3: Diagram of how trucks were lined up at the asphalt plant.}

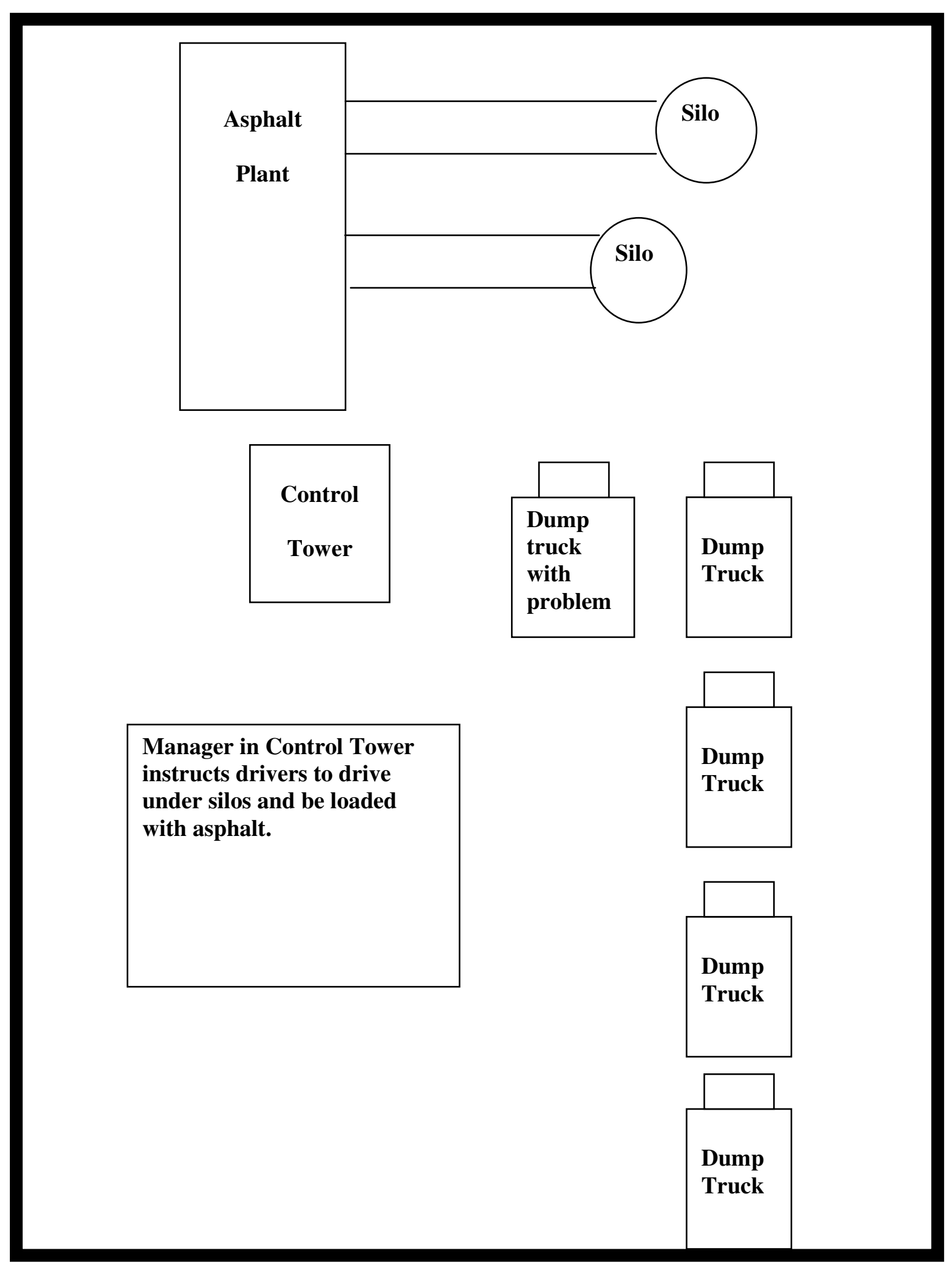




\section{Attachment 4: Diagrams of power-take-off drive shafts}

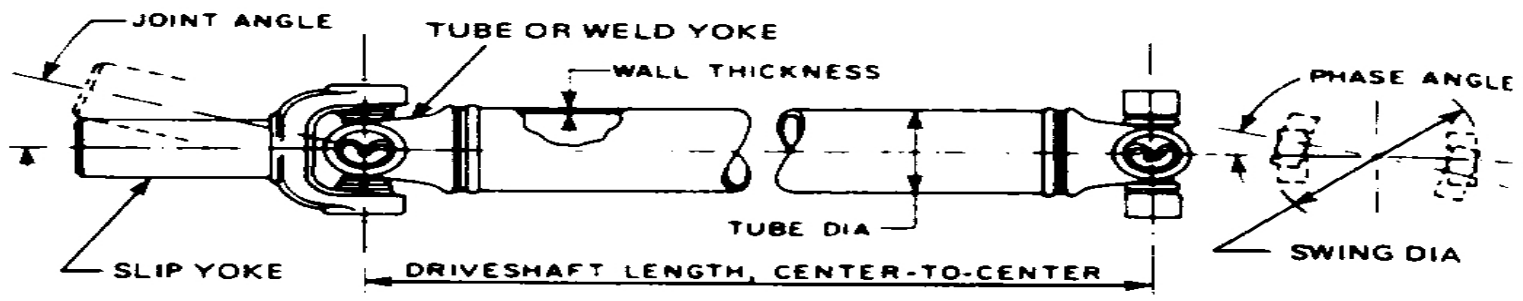

(a) TWO-JOINT OUTBOARD SLIP DRIVESHAFT

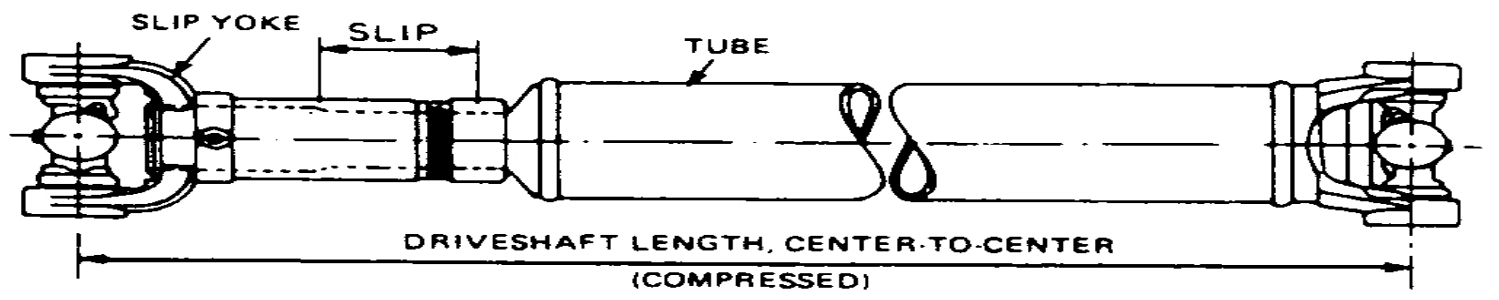

(b) TWO-JOINT INEOARD SLIP DRIVESMAFT

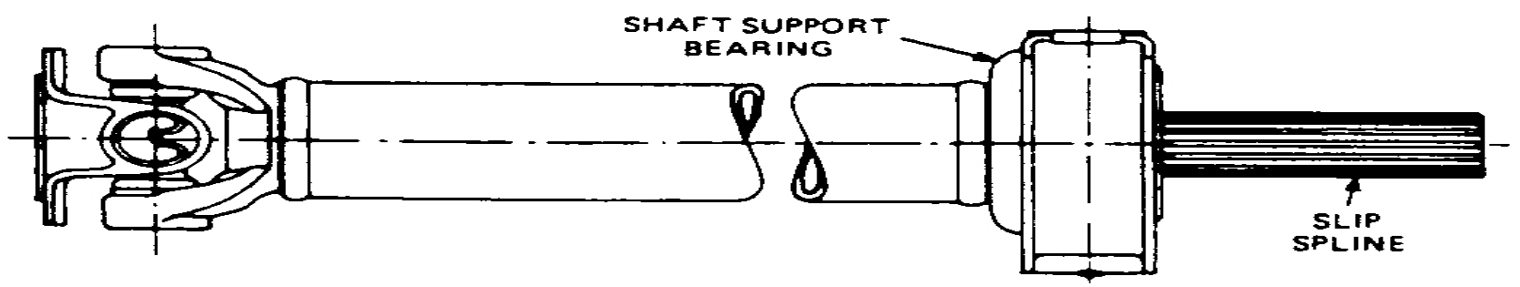

(C) SINGLE JOINT COUPLING SHAFT

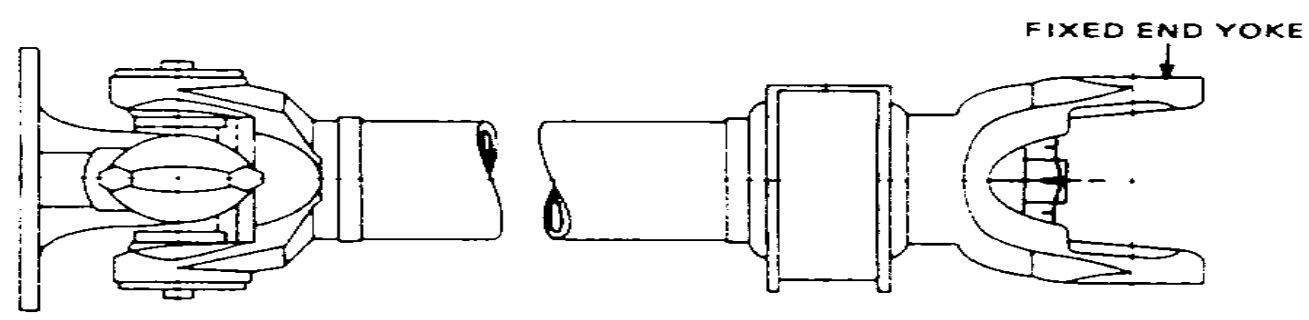

(d) SINGLE JOINT COUPLING SHAFT

FIGURE 1-BASIC DRIVESHAFT CONSTRUCTIONS

2005 Society of Automotive Engineers Handbook, Vol. 2, Parts \& Components and OnHighway Vehicles, Part I, Section 29, Page 92 
Attachment 5: Photo of dump truck being serviced at company garage.

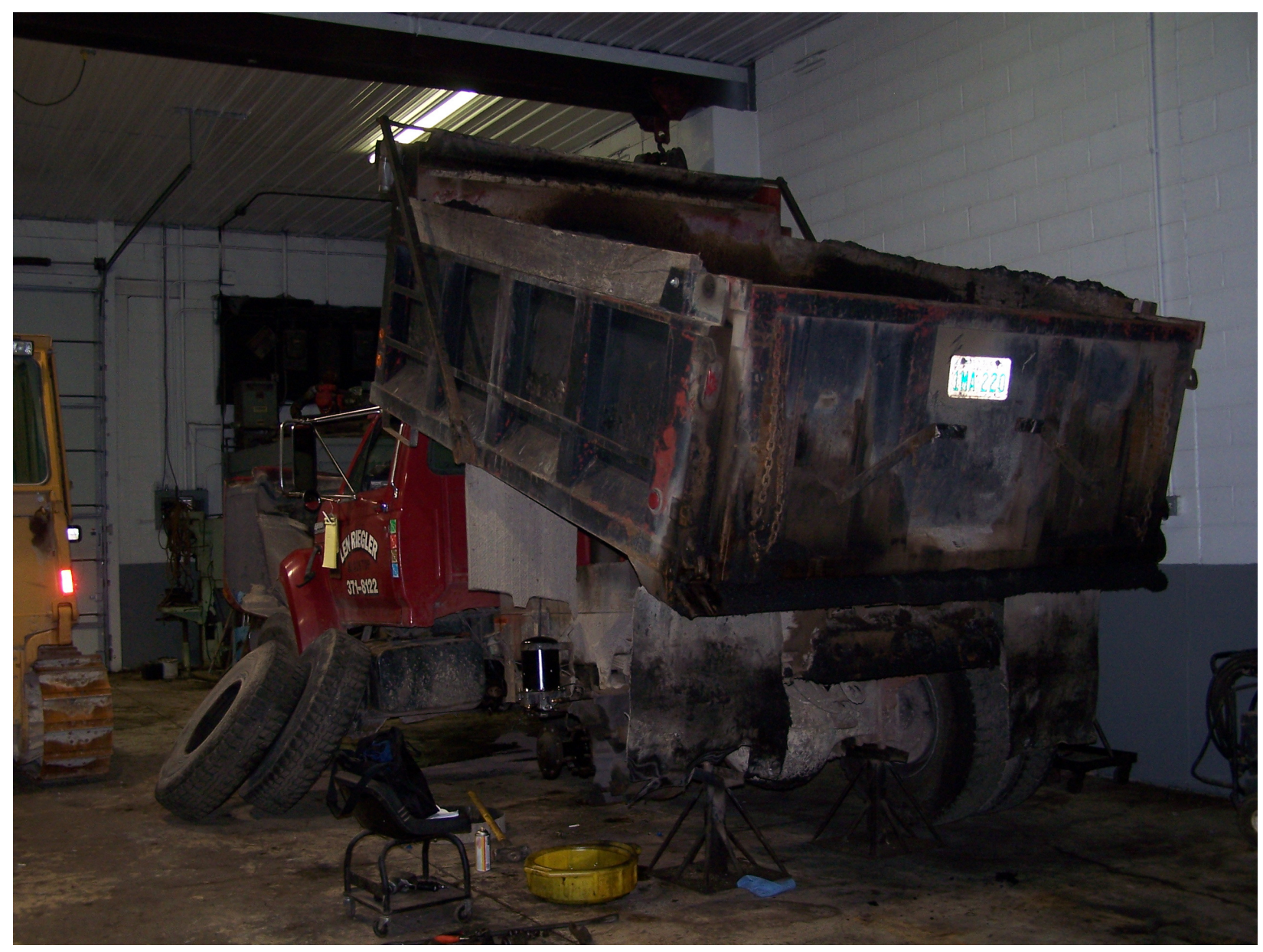

